\title{
THE DEVELOPMENT OF THE MARKET OF THE PRODUCTION OF SOLAR ENERGY IN POLAND AND SELECTED EU COUNTRIES IN THE YEARS 2009-2014 - COMPARATIVE ANALYSIS
}

\author{
Weronika DOROZIŃSKA, Maciej GAWRON, Paulina STAŃKO, \\ Natalia STĘPIEŃ, Patrycja ŚWISTAK \\ University of Zielona Góra \\ Han Yeon $\mathrm{JI}$ \\ Chung-Ang University
}

\begin{abstract}
:
The paper discusses issues related to the development of solar energy production in Poland and selected EU countries in the years 2009-2014. The analysis of data concerning the production of solar energy in Poland and selected EU countries is presented as well as the strategic goals of the Union in respect the development of the 'solar energy industry'. The article discusses the benefits and costs of the transformation of energy engineering and development of the production of solar energy, which is one of the most widespread and popular technologies of the production of energy from renewable resources in view of environment protection or reduction of the costs of energy consumption.
\end{abstract}

Key words: ecology, renewable energy resources, production of solar energy, development, transformation

\section{INTRODUCTION}

Since the accession to the European Union in 2004, Poland has been obliged to meet the requirements specified in the climate-energy package. The task additionally includes reporting on all forms of actions related to environment protection and observing the standards and recommendations expressed in the EU directives. The climate policy of the EU and UN gradually becomes more rigorous and demanding, the price of energy resources tends to increase, whereas natural resources in Poland are less available in view of the need to protect them and well as increasing costs. Yet the share of renewable resources in the energy balance increases.

The issue of the use of renewable energy sources (RES) in Poland and EU countries is also connected with the question of 'energetic security'.

The very concept of RES has relatively recently gained a new significance in view of the sustainable development of the energy sector due to the difficult geopolitical situation, mainly in Ukraine and disruptions in the transfer of gas from Russia.

The situation extorts the need to look for additional, alternative sources of energy improving the energy security of Poland. Furthermore the background literature indicates that solar energy is one of the most popular alternative sources of energy. Hence the paper discusses the problem of the development of the market of the production of solar energy in Poland and selected EU countries.

\section{EU STRATEGIC GOALS FOR THE DEVELOPMENT OF THE PRODUCTION OF SOLAR ENERGY}

Traditional forms of obtaining energy result in excessive pollution of the environment, for instance by the emission of the carbon dioxide, which is harmful not only for the environment but also for people. Additionally, the use of non-renewable sources of energy leads to the reduction of their resources, which is adverse for the economy, still largely dependent on them.

Ecological ideas, to large extent implemented in practice, LED to the development of photovoltaic cells, or solar panels, which convert solar energy in electric current, relevant for the functioning of the contemporary society [11]. Co-financing covering all the costs connected with the construction of solutions in the sphere of the use of solar energy as well as research whose aim is to extend the scope of the achievements in respect of the use of solar energy, are particularly important here [12].

The European Union has become one of the leading international organizations stressing the need to develop and implement new mechanism of supporting the RES sector. According to article 194 of the 'Treaty on Functioning of the European Union', the aim is to offer help to Member States by supporting the energy efficiency, developing new forms of renewable solar energy, or connections between energy grids [16].

The scope of the aims includes the assurance of the functioning of the energy market, in this case the market of electric energy, on which energy is traded. The last of the EU goals specified in the Treaty applies to the 4 assurance of security of energy supply in Europe. All this is expected to 
lead to the improvement of the condition of the natural environment, which is highly relevant for the appropriate functioning of people.

In order to achieve the goals specified in the Treaty, the European Union after the approval of the 'Energy for the future' White Paper, assumed that until 2010 energy obtained from renewable sources will total at $12 \%$, out of which $22.1 \%$ will be electric energy [17]. When in 2004 new countries joined the European Union, it was decided to increase the share of energy from renewable resources to $21 \%$, which led to a lack of progress in achieving the goals and acceptance of a wider legal framework [14].

"The renewable energy roadmap" report of January 10th, 2007 presented the strategy of the European Union concerning the renewable energy sources until 2010. The European Committee suggested that the use of renewable energy in the European Union should total at $20 \%$, whereas $10 \%$ of all the fuel used in transport should be bio-fuel. Additionally a new legal framework was proposed, and during the spring summit of the Council of Europe in 2007 the goals were approved by the political leaders of the EU [17].

The share of solar energy in the realization of the goals set by the European Committee, with the Assumption that the total demand for energy is reduced by $9 \%$, could amount at $2.4 \%$ and $3.6 \%$ according to the RDP - Full R\&Dand Policy scenario or $2.4 \%$ according to the AMD Advanced Market Deployment scenario [1]. Whereas taking into account the increase by $8 \%$ of the share of renewable energy in $27 \mathrm{EU}$ countries, the share of the solar energy according to the RDP scenario would amount at $12 \%$, w according to the AMD scenario by $4.5 \%$, while in case of the BAU scenario at $2.9 \%$. The accomplishment of these goals requires the average annual growth of the European solar energy market by $26 \%$ in case of the RDP scenario, $15 \%$ in case of the AMD scenario and $7 \%$ in case of the BAU scenario [1]. From the economic point of view, the realization of the RDP scenario requires 214 billion Euro, which cover the cost of production, trade, engineering and installation of the systems between 2006 and 2020 [1].

Thanks to the strategy of the European Union concerning the use of energy from renewable sources, including solar energy, already in 2014 the emission of $\mathrm{CO}_{2}$ in installations participating in the European System of Trading Emissions was reduced by $4.5 \%$. According to Miguel Arias Cañete, the European Commissioner for climate and energy Policy, this proves that despite significant economic development it is possible to take care of climate protection, especially by significant reduction of the emission of the carbon dioxide into the atmosphere. This undoubtedly contributes to further progress in the strategy assumed by the European Union in respect of the increase in the use of renewable energy [3].

The strategic goals of the European Union follow the principle of sustainable development, directed at broadly understood well-being of present and future generations. This direction of the development has specific implications, also for the development of the energy sector and results in new instruments supporting new technologies concerning for instance production of solar energy, or other forms of production of renewable energy. Increasingly more actions are taken in respect of the development of such investment. The strategic goals of the EU include the period after 2020, so that the policy for the investors could be prepared in advance, after the realization of goals of the previous strategy have been accomplished [6].

\section{BENEFITS AND COSTS OF THE TRANSFORMATION OF EN- ERGY PRODUCTION AND THE DEVELOPMENT OF THE PRO- DUCTION OF SOLAR ENERGY.}

In several countries (among others in Denmark, Germany or France), the transfer towards sustainable economies was accomplished by means of renewable sources of energy. The transformation in energy production based on 'ecological modernization' of the production market included energy saving as well as broadly understood increase of the energy efficiency, all in accordance with the principles of sustainable development. The goal of the transformation was to replace completely all non-renewable sources by renewable sources which are safe for the environment. The benefits of the transformation include more effective environment protection, increase of the number of work places be creating new research center, increase in the interest in the sources in view of decreasing costs of the purchase of Technologies, increase in the efficiency of energy production and better administrative as well as legal situation. According to Graczyk, Kaźmierczak-Piwko (2014): 'In the consequence of efficient continuation of the processes of 'ecological modernization' (...), the market of energy production may become one of the major areas of the realization of the postulate of full employment' in the future, since the RES sector, which can be observed in Germany, generates more workplaces compared to the sector of conventional energy production. Already in 2011 the number of persons employed in the RES sector in Germany was two time bigger than in the sector of conventional energy [8].

The newly planned act on renewable energy resources assumes that the market of solar energy will become more transparent. As part of the policy of sustainable development, the act will assure income from the sale of electric energy obtained from collectors and additional income from the sale of so called 'green certificates'.

Another benefit assumed be the new law consists in exempting micro - and small power plants from the need to run business activity and the requirement of possessing concessions for the production of electric energy will be abolished. The biggest benefit for potential power plants will consist in the fact that the distributors of energy will not collect fees for connecting micro-installations to the grid. Undoubtedly the act as well as changes in financing as well as support for small power plants will encourage investment into solar energy in Poland, and year by year the cost-effectiveness of the technology will increase.

Solar energy production in European countries is one of the fastest developing branches of the production of renewable energy. Both in the public discourse as well as in economic practice the practical application of 'green technology', which protects climate and reduces the emission of the carbon dioxide has been observed. Renewable energy gradually becomes more popular, so that in the future the costs of the purchase of energy could be reduced. The production of small amounts of electric energy used e.g. by households, requires solar collectors. If more energy is needed large amounts of photovoltaic cells combined into solar farms must be used [4]. Energy obtained in this way can be used for current purposes e.g. production, or sold to companies specializing in the distribution of electric energy.

It is estimated that at present only $0.02 \%$ of the energy of the Sun radiation which reaches the surface of the earth is used. The developer of the solar energy production was initially slow due to high production costs and limited inter- 
est. Polish producers developing the production of solar collectors reached foreign markets and $50 \%$ of the produced facilities is exported. While observing the recent development of the branch of the production of solar energy, it can be noticed that doubling of the volume of installed power results in $20 \%$ dicrease of the price of photovoltaic panels, whereas in Europe the costs of photovoltaic plants fell by $50 \%$ over the last 5 years. Further decrease of prices of solar panels by $36-51 \%$ is expected in the near future [10].

In 2008 the tempo of the sale of solar installations grew significantly and the country occupies the seventh position on the solar energy market in EU, which is better than in such countries like Portugal or Spain. Although the development is still not distinctive, the research conducted by the Institute of Renewable Energy indicates that the develop- ment of the production of solar energy may reach the level of $40 \%$ in 20140. 'In 2008 Spain was the biggest market of solar energy in the world. In 2014 fewer PVs were installed than in Poland', this quotation perfectly shows the potential of Poland in respect of the development of the production of renewable energy [2].

Solar energy production is encouraged by various credits, EU funds or funds of Rother state institutions. The best known institutions supporting the development of photovoltaic investment include:

- The National Fund for Environment Protection,

- Regional funds for environment protection and water management,

- Bank Ochrony Środowiska (Environment Protection Bank),

- Ekofundusz (Ecofund) [7].

Table 1

The structure of acquisition of energy in selected EU states in the years 2008-2012

\begin{tabular}{|c|c|c|c|c|c|c|c|c|c|c|c|c|}
\hline \multicolumn{2}{|c|}{ Specification } & UE-28 & Austria & $\begin{array}{c}\text { Czech } \\
\text { Republic }\end{array}$ & Estonia & Finland & Lithuania & Litvia & Germany & Poland & Slovakia & Sweden \\
\hline & & \multicolumn{11}{|c|}{$w \%$} \\
\hline & 2008 & 50,0 & 49,3 & 81,2 & 97,8 & 80,5 & 88,8 & 82,4 & 37,8 & 97,7 & 48,7 & 53,2 \\
\hline & 2009 & 49,4 & 47,5 & 75,9 & 97,4 & 80,6 & 85,7 & 82,8 & 39,6 & 86,0 & 52,9 & 54,5 \\
\hline \multirow[t]{5}{*}{ Solid biofuels } & 2010 & 49,4 & 52,3 & 72,2 & 97,0 & 82,5 & 84,6 & 84,5 & 41,4 & 85,6 & 52,7 & 55,9 \\
\hline & 2011 & 48,6 & 53,8 & 68,6 & 96,2 & 83,4 & 84,6 & 84,0 & 37,0 & 85,3 & 56,5 & 54,0 \\
\hline & 2012 & 47,2 & 50,1 & 66,3 & 95,9 & 79,7 & 82,8 & 80,2 & 35,9 & 82,4 & 55,9 & 51,7 \\
\hline & 2008 & 1,3 & 1,4 & 0,2 & - & 0,0 & - & - & 3,3 & 0,0 & - & 0,1 \\
\hline & 2009 & 1,8 & 1,5 & 0,5 & - & 0,0 & - & - & 4,2 & 0,1 & - & 0,1 \\
\hline \multirow[t]{5}{*}{ Solar energy } & 2010 & 2,3 & 1,9 & 2,1 & - & 0,0 & - & - & 5,3 & 0,1 & 0,4 & 0,1 \\
\hline & 2011 & 3,8 & 2,2 & 6,5 & - & 0,0 & - & - & 7,5 & 0,1 & 2,8 & 0,1 \\
\hline & 2012 & 5,1 & 2,1 & 6,1 & - & 0,0 & 0,0 & - & 8,6 & 0,2 & 2,9 & 0,1 \\
\hline & 2008 & 20,7 & 39,8 & 7,2 & 0,3 & 16,0 & 3,3 & 15,0 & 7,4 & 3,4 & 33,6 & 38,0 \\
\hline & 2009 & 19,7 & 41,5 & 8,1 & 0,3 & 13,8 & 3,1 & 14,2 & 6,6 & 3,4 & 30,7 & 35,8 \\
\hline \multirow[t]{5}{*}{ Water energy } & 2010 & 19,8 & 36,9 & 8,3 & 0,2 & 11,8 & 3,9 & 14,4 & 6,2 & 3,7 & 32,2 & 33,6 \\
\hline & 2011 & 16,5 & 34,9 & 5,6 & 0,3 & 11,7 & 3,6 & 12,0 & 5,0 & 2,7 & 23,4 & 34,5 \\
\hline & 2012 & 16,2 & 39,1 & 5,6 & 0,3 & 14,6 & 3,0 & 13,7 & 5,5 & 2,1 & 24,6 & 36,7 \\
\hline & 2008 & 7,5 & 2,1 & 0,9 & 1,5 & 0,2 & 1,1 & 0,3 & 15,1 & 1,3 & 0,1 & 1,1 \\
\hline & 2009 & 7,8 & 2,0 & 1,0 & 1,9 & 0,3 & 1,2 & 0,2 & 13,7 & 1,5 & 0,0 & 1,4 \\
\hline \multirow[t]{5}{*}{ Wind energy } & 2010 & 7,9 & 2,0 & 1,0 & 2,4 & 0,3 & 1,6 & 0,2 & 11,4 & 2,1 & 0,0 & 1,8 \\
\hline & 2011 & 9,5 & 2,0 & 1,1 & 3,2 & 0,5 & 3,5 & 0,3 & 14,1 & 3,7 & 0,0 & 3,2 \\
\hline & 2012 & 10,0 & 2,2 & 1,1 & 3,5 & 0,4 & 3,9 & 0,4 & 13,2 & 4,8 & 0,0 & 3,3 \\
\hline & 2008 & 4,8 & 2,1 & 3,7 & 0,4 & 0,5 & 0,3 & 0,5 & 13,2 & 1,8 & 1,0 & 0,7 \\
\hline & 2009 & 5,1 & 1,8 & 5,0 & 0,3 & 0,5 & 0,4 & 0,5 & 14,5 & 1,6 & 1,3 & 0,7 \\
\hline \multirow[t]{3}{*}{ Biogas } & 2010 & 5,2 & 1,7 & 6,1 & 0,4 & 0,4 & 0,8 & 0,6 & 14,9 & 1,7 & 1,0 & 0,7 \\
\hline & 2011 & 6,4 & 2,0 & 8,2 & 0,3 & 0,6 & 1,0 & 1,1 & 17,4 & 1,8 & 3,3 & 0,7 \\
\hline & 2012 & 6,8 & 2,2 & 11,5 & 0,3 & 0,6 & 1,0 & 2,2 & 19,5 & 2,0 & 4,3 & 0,7 \\
\hline
\end{tabular}


The structure of the production of electric energy from renewable sources in selected EU countries in the years 2008-2012

\begin{tabular}{|c|c|c|c|c|c|c|c|c|c|c|c|c|}
\hline \multicolumn{2}{|c|}{ Specification } & UE-28 & Austria & $\begin{array}{c}\text { Czech } \\
\text { Republic }\end{array}$ & Estonia & Finland & Lithuania & Litvia & Germany & Poland & Slovakia & Sweden \\
\hline & 2008 & 10,0 & 7,5 & 31,4 & 13,7 & 36,2 & 10,0 & 0,2 & 9,8 & 50,9 & 10,5 & 11,0 \\
\hline & 2009 & 10,2 & 7,2 & 30,0 & 56,7 & 38,7 & 12,7 & 0,1 & 10,0 & 56,5 & 10,0 & 12,7 \\
\hline \multirow[t]{5}{*}{ Solid biofuels } & 2010 & 10,4 & 8,0 & 25,3 & 69,9 & 43,7 & 12,7 & 0,2 & 10,3 & 54,2 & 10,2 & 12,5 \\
\hline & 2011 & 10,9 & 9,0 & 23,3 & 65,0 & 44,8 & 10,9 & 0,4 & 9,2 & 54,4 & 13,6 & 11,5 \\
\hline & 2012 & 10,5 & 7,3 & 22,5 & 66,7 & 37,5 & 14,9 & 1,6 & 8,5 & 56,5 & 13,2 & 10,7 \\
\hline & 2008 & 1,3 & 0,1 & 0,3 & - & 0,0 & - & - & 4,8 & - & - & 0,0 \\
\hline & 2009 & 2,4 & 0,1 & 1,9 & - & 0,0 & - & - & 7,0 & - & - & 0,0 \\
\hline \multirow[t]{5}{*}{ Solar energy } & 2010 & 3,4 & 0,2 & 10,4 & - & 0,0 & - & - & 11,2 & - & 0,3 & 0,0 \\
\hline & 2011 & 7,0 & 0,4 & 30,1 & - & 0,0 & - & - & 15,9 & - & 7,9 & 0,0 \\
\hline & 2012 & 9,3 & 0,7 & 26,6 & - & 0,0 & 0,2 & - & 18,5 & 0,0 & 7,7 & 0,0 \\
\hline & 2008 & 58,8 & 85,8 & 54,2 & 14,2 & 61,6 & 66,8 & 96,8 & 21,5 & 32,6 & 88,5 & 84,8 \\
\hline & 2009 & 56,0 & 86,6 & 52,2 & 5,9 & 58,5 & 62,0 & 97,2 & 19,7 & 27,4 & 88,9 & 82,5 \\
\hline \multirow[t]{5}{*}{ Water energy } & 2010 & 55,2 & 85,3 & 47,3 & 2,6 & 53,4 & 59,3 & 96,8 & 19,6 & 26,8 & 88,5 & 80,9 \\
\hline & 2011 & 45,8 & 83,7 & 27,1 & 2,5 & 51,5 & 43,2 & 93,8 & 14,0 & 17,7 & 75,6 & 79,0 \\
\hline & 2012 & 43,5 & 85,5 & 26,4 & 2,8 & 59,1 & 35,8 & 90,2 & 14,8 & 12,1 & 75,0 & 80,3 \\
\hline & 2008 & 21,4 & 4,5 & 6,6 & 67,5 & 0,9 & 21,8 & 1,8 & 43,8 & 12,7 & 0,2 & 2,5 \\
\hline & 2009 & 22,5 & 4,2 & 6,2 & 36,0 & 1,3 & 23,1 & 1,4 & 40,9 & 12,4 & 0,1 & 3,1 \\
\hline \multirow[t]{5}{*}{ Wind energy } & 2010 & 22,1 & 4,6 & 5,7 & 26,5 & 1,2 & 24,6 & 1,3 & 36,2 & 15,3 & 0,1 & 4,3 \\
\hline & 2011 & 26,6 & 4,7 & 5,5 & 31,2 & 2,0 & 42,7 & 2,3 & 39,6 & 24,4 & 0,1 & 7,2 \\
\hline & 2012 & 26,9 & 4,8 & 5,2 & 29,4 & 1,7 & 45,6 & 2,8 & 35,5 & 28,1 & 0,3 & 7,3 \\
\hline & 2008 & 4,4 & 1,3 & 7,2 & 4,6 & 0,1 & 1,5 & 1,2 & 14,0 & 3,8 & 0,3 & 0,0 \\
\hline & 2009 & 4,7 & 1,3 & 9,5 & 1,3 & 0,1 & 2,2 & 1,3 & 15,9 & 3,7 & 0,4 & 0,0 \\
\hline \multirow[t]{3}{*}{ Biogas } & 2010 & 4,7 & 1,4 & 10,8 & 1,0 & 0,4 & 3,4 & 1,6 & 16,7 & 3,7 & 0,6 & 0,0 \\
\hline & 2011 & 5,6 & 1,5 & 12,8 & 1,3 & 0,6 & 3,2 & 3,4 & 17,2 & 3,4 & 2,3 & 0,0 \\
\hline & 2012 & 6,1 & 1,2 & 18,2 & 1,1 & 0,5 & 3,6 & 5,4 & 19,1 & 3,3 & 3,5 & 0,0 \\
\hline
\end{tabular}

Source: [6].

Poland has a significant potential for the development of the production of solar energy. Objectively however, it is much smaller in comparison with our western neighbors. Germany set ambitious goals in respect of the development of solar energy which to large extent were accomplished and the development was impressive.

Yet in 2012 the act on renewable sources of energy was changed, and its purpose was to stabilize the increase in the number of new plant as well as reduce the costs of supporting RES.

The act did bring expected results and the market of solar energy in the Germany was in crisis. The fall was so drastic that the German photovoltaic market shrank by half and the number of workplaces was reduced from 111 thousand to 56 thousand.

\section{ANALYSIS OF DATA ON THE PRODUCTION OF SOLAR ENER- GY IN POLAND AND SLECTED EU COUNTRIES - LEADERS AND OUTSIDERS}

Considering the fact that both innovations and the wil to protect the environment from All forms of pollution increases with the level of ecological awareness, EU states, including Poland, put increasingly more emphasis on acquisition of energy from renewable sources. This includes solar energy, on which more emphasis is put not only in view of promotion of its use by the industrial sector but also by individual households [5]. It is important that the cost of acquiring solar energy is much lower in view of its availability, and the energy can sufficiently satisfy the demand of the entire planet. 
On the average in Poland during one year the power of solar energy for $1 \mathrm{~m} 2$ reaches $1000 \mathrm{kWh}$, which is equivalent to more than 100 liters of heating oil [15]. As part of the "operational program; infrastructure and environment" in the years 2007-2013 the European Union designated the budget of 860 million Euro for financing investments connected with renewable energy, including obviously solar energy. Considering the fact to each of the member states, according to the Directive 2009/28/We of the European Committee, is expected to increase its share in production of renewable energy by 2020 , the level for Poland was agreed for $15 \%$ [13]. Table 1 presents the structure of the acquisition of RES in selected EU countries in the years 2008-2013.

While referring to the report of the Central Statistical Office from 2013 on energy from renewable resources, it can be observed how Poland and other countries of the European union obtain energy and how it produced depending on the sources. Definitely Germany remain the leader in production of solar energy, when the in 2009 approximated $4.2 \%$, whereas four years later i.e. in 2012 increased to $8.6 \%$. The increase is the highest in European Union and amounts at $4.4 \%$ [6]. The Czech Republic has even higher increase in these years at level of $5.5 \%$. The general index for EU-28 states was $1.8 \%$ in 2009 and increased to $5.1 \%$ in 2012 . The growth in Poland is limited since as late as in 2011 the share in the acquisition of solar energy reaches $0.1 \%$ and increases to $02 . \%$ in the following year. There is no growth in such countries as Lithuania, Finland or Sweden [6]. Table 2 shows the structure of the production of electric energy from renewable sources in selected EU countries in the years 2008-2012.

While analyzing the table presenting the structure of electric energy from renewable sources and comparing it with previous set, it can be noticed that the Czech Republic and Germane are unquestionable leaders. The level of production on the territory of the Czech Republic in 2009 totaled at $1.9 \%$ whereas in 202 as much as $26.6 \%$ which means growth by several hundred percent. In case of Germany, it can be observed that initially the level approximated $7 \%$. In the following years the growth was so high that it reached $18.5 \%$ in 2012, which means impressive increase by $11.5 \%$. The index for eU-28 states was $9.8 \%$ in 2012 , which means development and growth by 6.9 percent relative to 2009. The results of Poland, in comparison with both leaders is bad as it is so low that approximates 0\% in 2012. This may result from the fact the bio-fuel is the main source of renewable energy in the country. In the group of countries with the zero result there are also Finland and Sweden which focus on other sources.

While referring to the above presented data from the report of the Central Statistical Office, it can be noticed that in subsequent years some countries such as the Czech republic or German put more emphasis on acquisition and production of solar energy. They attempt to meet the requirements included in the Directive 2009/28/WE and work on the positive image of their countries as well as acquisition energy from the source which is available at all times. In other countries, similarly to Poland, Finland or Sweden the growth is limited or cannot be observed like in the case of Estonia or Latvia. This can be caused by production of energy from other renewable resources. The argument that the sun is a inexhaustible source of clean energy, free and endless should be convincing [6].

\section{CONCLUSIONS}

For numerous years Poland has attempted to implement and meet the rigorous obligations included in the climate-energy package.

It can be observed that in the issues of broadly understood "energy security" enjoy increasingly stronger interest. The problem is highly significant and with time will gain in significance. Solar energy remains one of the most popular methods of acquiring energy from renewable sources and is widely used both in Poland and the world. Thanks to numerous campaigns supporting ecological ideas, the growth of interest in new, alternative and not conventional methods of acquiring energy. Poland should undertake numerous actions promoting the acquisition of energy from renewable sources, so that in this respect it could approach those countries of the European Union which are particularly successful in this area.

\section{REFERENCES}

[1] P. Biermayr, W. Weiss, Badania Potencjału Słonecznej Energetyki Cieplnej w Europie - Podsumowanie, Vienna University of Technology \& AEE - Institute for Sustainable Technologies Vienna University of Technology, [Online]. Available: www.estif.org.

[2] B. Derski, Energetyka słoneczna się przegrzała na Zachodzie. A w Polsce? [Online]. Available: http:// wysokienapiecie.pl.

[3] ECEA - Chiny i Unia Europejska wyraźnie zredukowały emisje CO2, [Online]. Available: http://ecea.eu.

[4] Energetyka solarna, [Online]. Available: http:// proecogroup.eu.

[5] Energia słoneczna, [Online]. Available: www.oze.pl.

[6] Energia ze źródet odnawialnych w 2013. Informacja i opracowanie statystyczne", GUS, Warszawa, 2014, [Online]. Available: www.stat.gov.pl

[7] Finansowanie inwestycji fotowoltaicznych w Polsce, [Online]. Available: http://ioze.pl.

[8] M. Graczyk, L. Kaźmierczak-Piwko, Ekoinnowacje na rynku wytwarzania energii - w stronę poprawy ekoefektywności i pełnego zatrudnienia, Przegląd Naukowo -Metodyczny, Numer 3/2014(24), Poznań 2014 r.

[9] Komunikat komisji z dnia 10 stycznia 2007 r. „Mapa drogowa na rzecz energii odnawialnej - Energie odnawialne w XXI wieku: budowa bardziej zrównoważonej przyszłości" [COM(2006) 848 wersja ostateczna - nieopublikowany w Dzienniku Urzędowym], [Online]. Available: http://eur-lex.europa.eu.

[10] Koszty produkcji energii z fotowoltaiki, [Online]. Available: www.zielonaenergia.eco.pl [11] E. Krac, K. Górecki, Współczesne problemy energetyki solarne, Zeszyty Naukowe Akademii Morskiej w Gdyni, nr 75, grudzień 2012.

[11] L. Łakomiec, Energia dla przyszłości: Odnawialne Źródła Energii, [Online]. Available: www.zb.eco.pl.

[12] A, Masiuk, K. Sieradzki, Rynek energii słonecznej w Polsce, [Online]. Available: http:// www.myfachowcy.info.

[13] Noty faktograficzne o Unii Europejskiej, [Online]. Available: www.europarl.europa.eu.

[14] Odnawialne źródła energii. Efektywne wykorzystanie $w$ budynkach. Finansowanie przedsięwzięć, Fundacja na rzecz Efektywnego Wykorzystania Energii, [Online]. Available: www.docplayer.pl. 
[15] Traktat o funkcjonowaniu Unii Europejskiej, Dziennik Urzędowy C 326, 26/10/2012 P. 0001 -0390, [Online]. Available: http://eur-lex.europa.eu.

[16] M. Zajączkowska, Polityka energetyczna Unii Europejskiej, Zeszyty Naukowe Uniwersytetu Ekonomicznego w Krakowie, nr 852, 2011 r.

Weronika Dorozińska, Maciej Gawron, Paulina Stańko

Natalia Stępień, Patrycja Świstak,

University of Zielona Góra

"Eco-Management" Student Research Club

ul. Podgórna 50, budynek A-0, 65-246 Zielona Góra, POLAND

e-mail: weronika-dorozinska@wp.pl, mgwr.gawron@gmail.com, pakii@o2.pl, Chill.out.pl@gmail.com, MarionleOszonte@wp.pl

Han Yeon Ji

Chung-Ang University, Seoul, SOUTH KOREA 